\title{
The Impact of a Systemic Innovation Sustainability Model on Students' Academic Performance in Oman
}

\author{
Mohamed El Tahir Osman ${ }^{1, *} \&$ Abdo Mohamed Al Mekhlafi ${ }^{1}$ \\ ${ }^{1}$ ILT Department, College of Education, Sultan Qaboos University, Sultanate of Oman \\ *Corresponding author: Sultan Qaboos University, Sultanate of Oman. E-mail: \\ musaabmt@gmail.com
}

Received: February 28, 2018 Accepted: March 7, 2018 Published: March 31, 2018

doi:10.5296/ije.v10i1.12931ＵRL: https://doi.org/10.5296/ije.v10i1.12931

\begin{abstract}
In light of the need for improving the quality of education and extending the boundaries of students' learning potential, the Sultanate of Oman has exerted efforts in reforming and restructuring its education system during the past four decades. However, most of the reform initiatives focused on either subsystems or certain driving forces in the education system, and thus, did not result in a sustained school improvement (Osman, 2011). This status quo has led to initiating a large cope project which aims to systemically activate the impact of all interrelated elements in the school system that promote the empowerment of student learning in the Sultanate of Oman. As part of this project, this study aims to examine the collective impact of the proposed model (The Innovation Sustainability Wheel- ISW) on students' academic performance. The sample included a total of 5513 students from eight schools, divided into two groups: the experimental consists of 2906, and a control group of 2607 students (grades 5 -9). The students' performance was tested over three years in five subject areas (Math, Science, English, Arabic and IT). The findings revealed that students of the experimental group outperformed their counterparts in the control group both collectively and in each single subject area.
\end{abstract}

Keywords: systems approach, school improvement, innovation sustainability, students performance Oman 


\section{Introduction}

Research on school improvement models have shown that contextualized systemic approaches to educational reform produce positive changes in the school operational processes, which in return, result in significant increases in student achievement (City, Elmore, Fiarman, \& Teitel, 2009; Darling-Hammond et al., 2002; Dufour et al., 2005; Leithwood et al. 2007; Stevens\& Kahne, 2006). Worldwide, many researchers, educators, politicians, and policy-makers are involved in reform efforts to improve educational systems for achieving better student outcomes. Such reform efforts often include a wide variety of strategies and action plans to help schools improve further. All schools expect their students to succeed in every aspect of life. When schools focus on specific goals and strategies for change and innovation, they may make a lasting effect. This calls for an appropriate plan for systematic school improvement. The concept of 'school improvement' is about the steps the schools take to accept the areas of change which a school needs in order to improve the level of academic achievement.

In light of the need for improving the quality of education and extending the boundaries of students' learning potential, the Sultanate of Oman has made concerted efforts in reforming and restructuring its educational system during the past four decades. However, most of the reform initiatives focused on either subsystems or certain driving forces in the education system, and thus, resulting in a very little sustained school improvement (Al Barwani and Osman, 2011). Given the contextual nature of school effectiveness models, it can be argued that schools should develop their own improvement mechanisms and make use of data emerging from the feedback for improving the teaching practice and the school learning environment.

Based on a review of a plethora of research on school effectiveness and sustainability of educational innovations, Al Barwani and Osman (2011) have developed the requirements for sustainable school improvement in what they call the 'Innovation Sustainability Wheel' (See Figure1). The Innovation Sustainability Wheel Model was developed as a tool for analyzing the fit and readiness of educational innovations, and to identify the missing links that may impact the life span and potential sustainability of any innovation. The ISW is rooted in the theories of change, the complexity theory (Davis, 2008; Mason, 2009), social constructivism, systems theory, and the principles of the diffusion of innovations (Rogers, 2003). The complexity theory, for example, concerns itself with environments, organizations, or systems that are complex in the sense that very large numbers of interrelated constituent elements are connected to and interacting with each other in various ways. In the context of the complexity of the educational environment, these constituent elements include teachers, students, parents and other community leaders, policy makers, economic structures and business organizations (King, 2009; Thoonen, et al. 2012). Based on this theoretical framework, it can be argued that school effectiveness is a function of a continuous momentum generated by many driving forces. It is assumed that the ISW provides a useful systemic approach for school improvement, where all the driving forces can be activated through relevant interventions. 


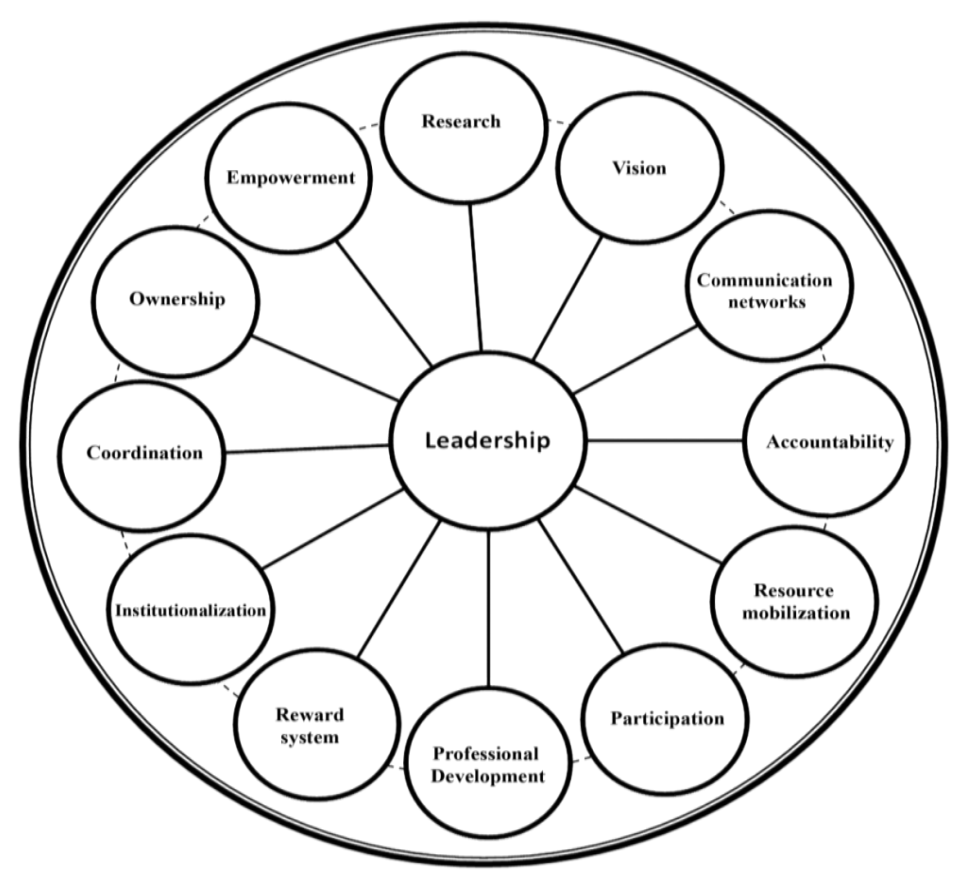

Figure 1. The Innovation Sustainability Wheel (ISW)

Al Barwani, T., \& Osman, M. (2011)

This study is part of a large scope project which aims to systemically activate and analyze the impact of all interrelated elements in the school system that promote the empowerment of student learning in the Sultanate of Oman. The project aims at furnishing the school system with a practical model for sustained improvement of the overall school performance. It is hypothesized that any sustained improvement in the school system is function of a set of interrelated driving forces or subsystems that collectively drive the overall performance of the school system, and impact students' learning potential. The purpose of this particular study is to examine the collective impact of the proposed model (The Innovation Sustainability Wheel- ISW) on students' academic performance. More specifically, this study aims to answer the following questions:

\section{Research Questions}

1. Are there any significant differences in students' performance between the control group and the experimental group in five subjects (Math, English, Science, English, Arabic and ITS) collectively across three years?

2. Are there any significant differences between the control and experimental groups in students' performance by subject?

3. Is there any significant improvement in the experimental group students' performance across three years? 


\section{Context and Review of Literature}

Although school improvement is rooted mostly on educational practice, there is also a felt-need for explicit theories on how to improve schools. Creemers and Reezigt (1997) observe that the school improvement literature pays more attention to the description of projects and to the formulation of practical advices for practitioners than to the development and systematical testing of theories on what to improve and how to do it. There is no doubt that theories cannot be based on best practices only. Many researchers have found out that there are no empirically validated theories on school improvement that can lead schools to higher level of performance. A useful contribution to theory development is the generic framework for school improvement delivered by Hopkins (1996). In this framework, three major components are depicted: educational givens, a strategic dimension, and a capacity building dimension. Educational givens cannot be changed easily. Givens can be external to the school (such as an external impetus for change) and internal (such as the school's background, organization and values). The strategic dimension refers to the competency of school to set its priorities for further development, to define student learning goals and teacher development, and to choose a strategy to achieve these goals successfully. The capacity-building dimension refers to the need to focus on conditions for classroom practice and for school development during the various stages of improvement. Finally, the school culture has a central place in the framework. Changes in the school culture will support teaching-learning processes which will in their turn improve student outcomes (1996)

It is true that there are no empirically validated theories of school improvement to lead schools to greater development. However, some researchers have attempted to formulate theoretical perspectives on school improvement and educational change. Sleegers and Leithwood (2010) identified two views on change which dominated the theoretical perspectives about school improvement and educational change. The first view is the 'Inside View' which focuses on the capacity of schools to transform themselves into supportive environments for teacher learning and change. The second view is the 'Outside view' which focuses on the implementation of external reform designs into schools. While literatures associated with both inside and outside views of change complement each other, they are based on different assumptions. According to Sleegers and Leithwood, these assumptions are well captured in Chin and Benne's classic distinction between normative-reductive approaches and empirical rational approaches to change.

According to Thoonen et al. (2012), the Normative -deductive approach of change focuses on the professional growth of individuals who make up the system and on the problem-solving capacities of the system itself. In this approach, change is considered an important part of a larger process in which teachers work and live through individual and collective reflection on beliefs and practices. The empirical-rational approach focusses on research-based models for change which assume that teachers, as rational human beings, will implement changes in their classrooms which are demonstrated to improve student learning. Empirical-rational strategies view teachers a s mere recipients and consumers of behavior, beliefs, programs of researchers, policy makers, and educators outside the school. 
Hopkins (2201) and Leithwood, Aitken, \& Jantzi (2001) state that the inside view is represented by a wide range of studies about organizational learning, learning organization, and professional communities by focusing on the capacity of schools to transform themselves into supportive environments for teacher learning and change. In these studies, organizational conditions including leadership are the main agents of school's capacity to change and a prerequisite for linking teachers' professional development to school development. The outside view is concerned with the implementation of innovations or new practices developed by reformers and policy makers, is represented by studies into the effects of the comprehensive school reform (CSR) models and the transfer of these models to multiply settings (scaling up). According to Berrends et al. (2002), these studies use quasi-experimental designs to assess the impact of different aspects of school operations, including instruction, assessment, classroom management, professional development, parental involvement, school management, and curriculum on student learning. As a result, most research work on school improvement focuses on the conditions under which these models can be implemented successfully, the possibilities of scaling up CSR models, and the sustainability of these educational reforms. The findings of the study show that most CSR reforms were actively shaped and reshaped ('co structured') by teachers, school leaders, and other local educators to accommodate the various goals, materials, and demands of the program to the local context. Although the inside and outside views are based on different assumptions, they complement each other in many ways.

For the purposes of school improvement, successive governments in the U.K emphasized the benefits of external inspections by a non-ministerial body such as the office for standards in education. and self-evaluation measures. Some schools selected in the U.K for whole school improvement program adapted the tenets of SFBT to investigate whether effective systems could be developed within schools so that improvement could be sustained. Research on the success of school improvement programs using solution-focused type of approach such as SFBT has been inconclusive because of inappropriate application of outcome measures, and unexpected differences between comparison groups and small sample sizes. From the point of view of Franklin (2009), this may be due to the research investigating the positive effect of SFBT on outcomes which have no correlation to SFBT and fail to address the methodological limitations. According to Crowley and Hauser (2007), the evaluation of school improvement programs has also shown limitations in the methodology and varied regard for program fidelity.

The terms school effectiveness and school improvement are often interchangeably used, but Creemers and Reezigt (2005) distinguish between the two with the former being described as "what works and why" and the latter being policy and practice oriented to make changes in a specific direction. According to them (1995), a major aim in the field of school effectiveness always was to link theory development and research on the one hand and practice and policy making, especially school improvement, on the other hand. According to Mortimore (1991) school effectiveness has led to major shifts in educational policy in many countries by emphasizing the accountability of schools and the responsibility of educators to provide all children with possibilities for high achievement, thereby enhancing the need for school 
improvement. From the perspective of Hargreaves (1995), school effectiveness pointed at the need for school improvement in particular by focusing on alterable school factors. School improvement might point at inaccurate conceptions of effectiveness, such as the notion of linearity or one-dimensionality. This shows clearly that school improvement is not something that starts at given period of time and comes to an end at a time set for finishing a project, but it is an ongoing process. In school education, the term ongoing improvement/continuous improvement indicates that the process of school improvement progressively unfolds and that is sustained over period of time.

Hopkins (2001) identified five essential components for sustainable school improvement. The first component is the school improvement cycle which includes a set of procedures that creating and evaluating improvement plans such as self-evaluation and identifying improvement priorities. The second component is the Plan for Improving Achievement. The third focuses on improving teaching and learning. The fourth is tracking children and the fifth is student progress meetings. According to Hopkins, these components interact with and influence each other so that schools can improve further.

According to one of the common definitions, a school improvement plan is a road map that shows the changes a school needs to make to improve the level of student achievement, and how and when these changes will be made. Another definition explains that school improvement refers to quality improvement. School improvement also involves a disciplined use of evidence-based quantitative and qualitative methods to improve the effectiveness, efficiency, equity, timeliness, or safety of service delivery processes and systems. When educational systems engage in the process of school improvement, they need to embed the concept of quality improvement into the very systems, processes and functioning of schools. Some researchers define school improvement and the ongoing improvement planning as a systematic way of planning school improvement and tracking it over time.

\section{Methodology}

\subsection{Research Design}

This study is part of a large scope project which aims to systemically examine the overall performance of the participating schools, as well as their interrelated subsystems. Accordingly, a descriptive analytic methodology which draws upon mixed methods of quantitative and qualitative data were be used. The project has three phases (before, during, and post-intervention). Each phase required different types of design (e.g., descriptive analytic, experimental, and ethnography). For both within and between schools comparisons, baseline data on students' performance in various content areas (Science, Math, English language, Arabic Language, and Information Technology) was collected and measured against post intervention outcomes in light of the national standards and benchmarks. This particular study focuses on school improvement as measured by students' academic performance in five school subjects. 


\subsection{The Sample}

The population consists of all students in cycle two of Basic Education in Oman. The sample included eight male and female schools (4 experimental and 4 control schools) from Muscat area. Both the experimental and control schools were selected from a moderate size, and average performing schools in the same vicinity. A total of 5513 students from grades $5-10$ in these schools have been tested at three different stages: grades 5-6, 7-8, and 9-10. The sample is divided into two groups, the experimental consists of 2906, and a control group of 2607 students.

\subsection{Instruments}

The results of this study were based on students' performance in the Ministry of Education exams (students' literacy (Arabic and English), Math, Science and IT).

\subsection{Procedures}

The researchers used the Innovation Sustainability Wheel (ISW) as a theoretical model for systemic performance analysis and improvement. This model is based on an extensive review of literature illustrating the common driving forces that inevitably lead to an improved sustainable change. In this project, baseline data on students' performance in various content areas (Science, Math, English language, Arabic Language, and Information Technology) were collected. In addition, each of the driving forces in the model was examined and activated through relevant interventions. The project has three phases (before, during, and post-intervention). Data regarding the school operation processes (e.g., governance, leadership practices, instructional practices, evaluation, feedback mechanisms, professional development, and community involvement) were collected at various stages using the Ministry of Education's school performance indicators.

Research-based interventions in the selected content areas (Math, Science, English, Arabic, and IT) were introduced. Students were provided with opportunities for more engagement in meaningful learning. These include, but not limited to: interactive instructional and learning activities, inquiry, reflection and exploration, project-based learning, self-regulatory activities, and online collaboration. Instructional and learning technologies were integrated in all off-line and online students' engagement activities. In addition, school leaders, supervisors, and teachers were involved in relevant on-site professional development, and supported by supplementary online training resources.

For the purpose of the research interventions, the research team developed an interactive e-learning platform targeting teachers and students in the experimental schools. This Platform provides e-content and other open sources for both students and teachers in 5 subject areas (Science, Math, English, Arabic \& IT). In addition, a series of workshops have been conducted for the experimental participating schools. 


\section{Findings}

To answer the first question with regard to comparing the students' performance in five subjects (Math, English, Science, English, Arabic and IT) collectively across three years, an independent sample T-test was employed.

Table 1. An Independent Sample T-test to Compare Students' Performance across Three Years.

\begin{tabular}{|c|c|c|c|c|c|c|c|}
\hline Group & & $\mathrm{N}$ & Mean & Std. Deviation & $\mathrm{t}$ & df & $\operatorname{Sig}(2$ tailed) \\
\hline \multirow[t]{2}{*}{ TOTALL_2014 } & EXP & 2237 & 61.6019 & 31.33894 & 1.183 & 4164 & .237 \\
\hline & CONT & 1929 & 62.7144 & 28.94511 & & & \\
\hline \multirow[t]{2}{*}{ TOTALL_2015 } & EXP & 2590 & 68.4627 & 24.45011 & .535 & 4889 & .593 \\
\hline & CONT & 2301 & 68.8210 & 22.13483 & & & \\
\hline \multirow[t]{2}{*}{ TOTALL_2016 } & EXP & 2906 & 73.6669 & 14.56641 & 8.987 & 5511 & .000 \\
\hline & CONT & 2607 & 69.8664 & 16.82698 & & & \\
\hline
\end{tabular}

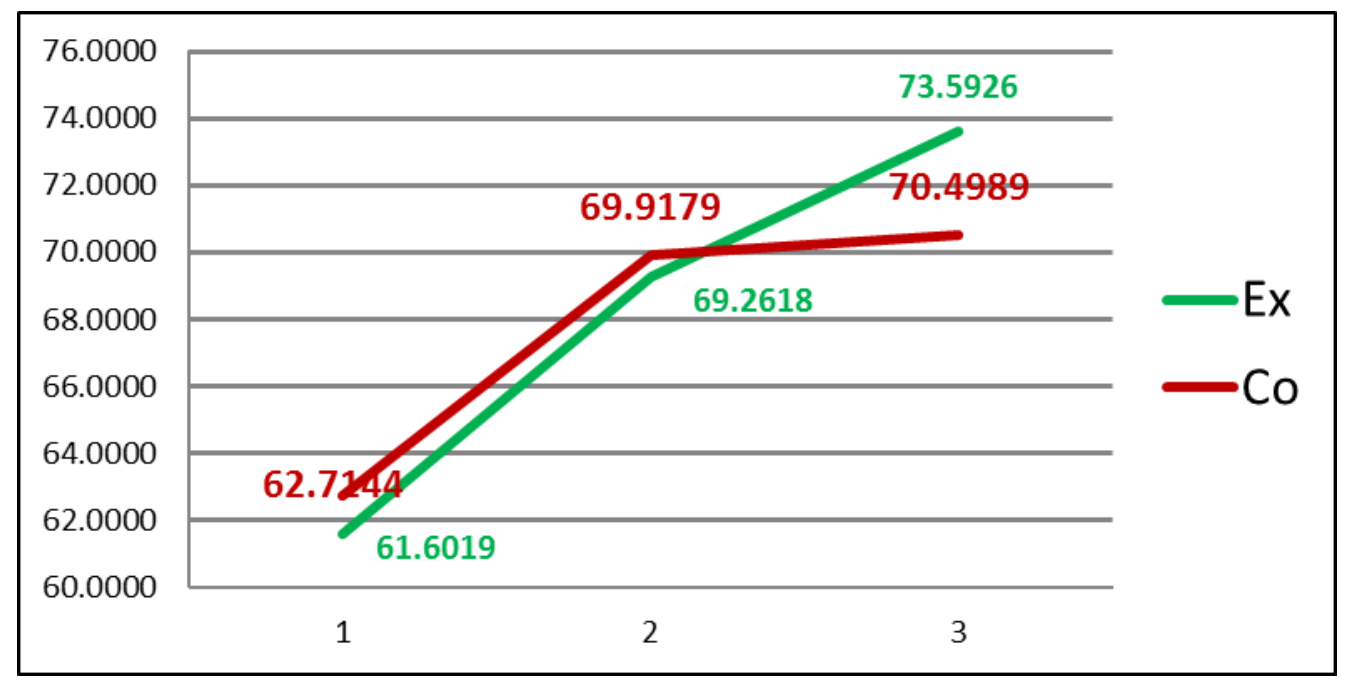

Figure 2. Comparison of Students' Performance in both the Experimental and Control Groups Across Three Years

As shown in Table (1) and figure (1) above the results reveal progressive improvement in students' performance in both groups across the three years. However, to the contrary of the first year, in 2016 the experimental group students outperformed the control group students significantly with a mean of (73. 67 , and 69.87 respectively) at 0.001 level of significance. 


\section{Macrothink}

This suggests an overall improvement in students' performance due to the treatments the students were exposed to throughout the project.

In order to compare the students' performance of both groups in the last year in each subject area (Math, English, Science, English, Arabic and IT) an independent sample T-test was used.

Table 2. Independent Sample T-test Comparing the Experimental and Control Groups by Subject Area

\begin{tabular}{llllllll}
\hline Group & & N & Mean & $\begin{array}{l}\text { Std. } \\
\text { Deviation }\end{array}$ & t & df & $\begin{array}{l}\text { Sig (2 } \\
\text { tailed) }\end{array}$ \\
\hline MathS120172016 & EXP & 2906 & 70.10 & & & 5511 & \\
& CONT & 2607 & 65.49 & 17.128 & 9.383 & & .000 \\
ScienceS120172016 & EXP & 2906 & 72.01 & 19.291 & & 5511 & .000 \\
& CONT & 2607 & 67.16 & 15.759 & 10.518 & & \\
EnglishS120172016 & EXP & 2906 & 74.47 & 18.468 & & 5511 & .000 \\
& CONT & 2607 & 71.04 & 18.564 & 6.611 & & \\
ArabicS120172016 & EXP & 2906 & 74.73 & 19.992 & & 5511 & .000 \\
& CONT & 2607 & 72.90 & 16.152 & 3.908 & & \\
ITS120172016 & EXP & 2906 & 77.03 & 18.686 & & 5511 & .000 \\
& CONT & 2607 & 72.75 & 15.868 & 9.281 & & \\
\hline
\end{tabular}

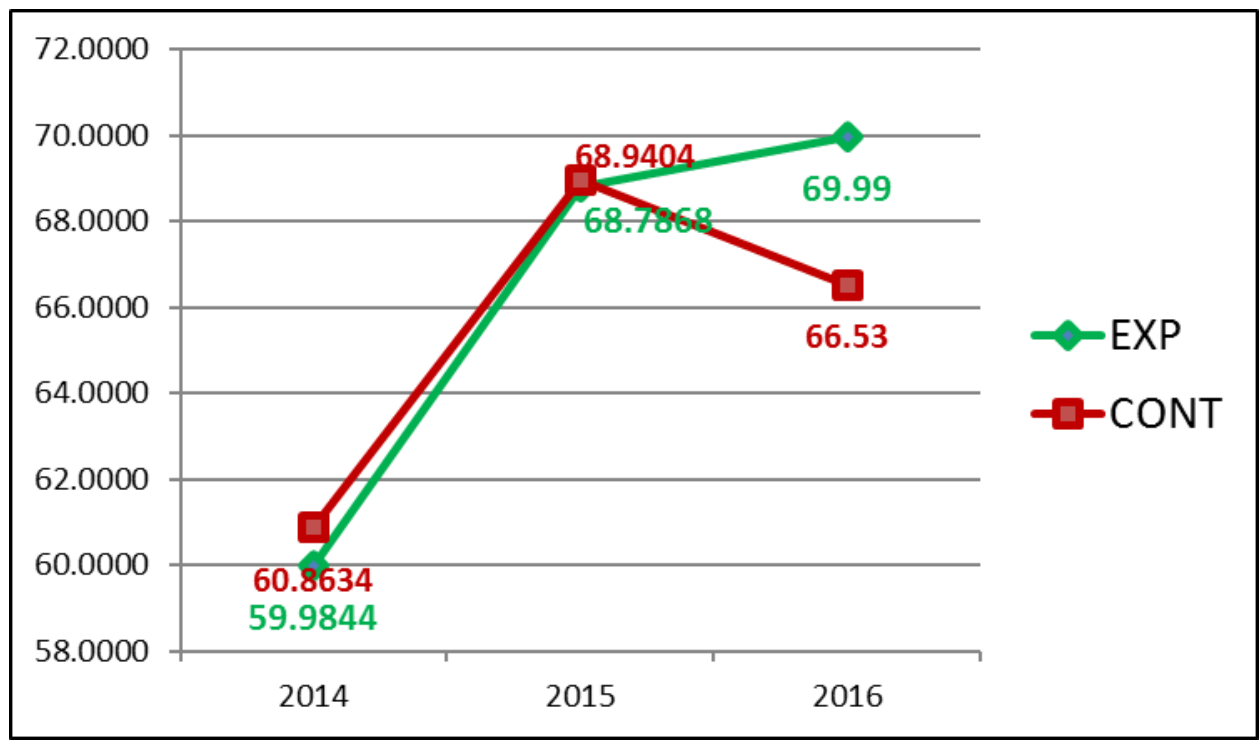

Figure 3. Comparison of Students' Performance in Math Across Three Years 


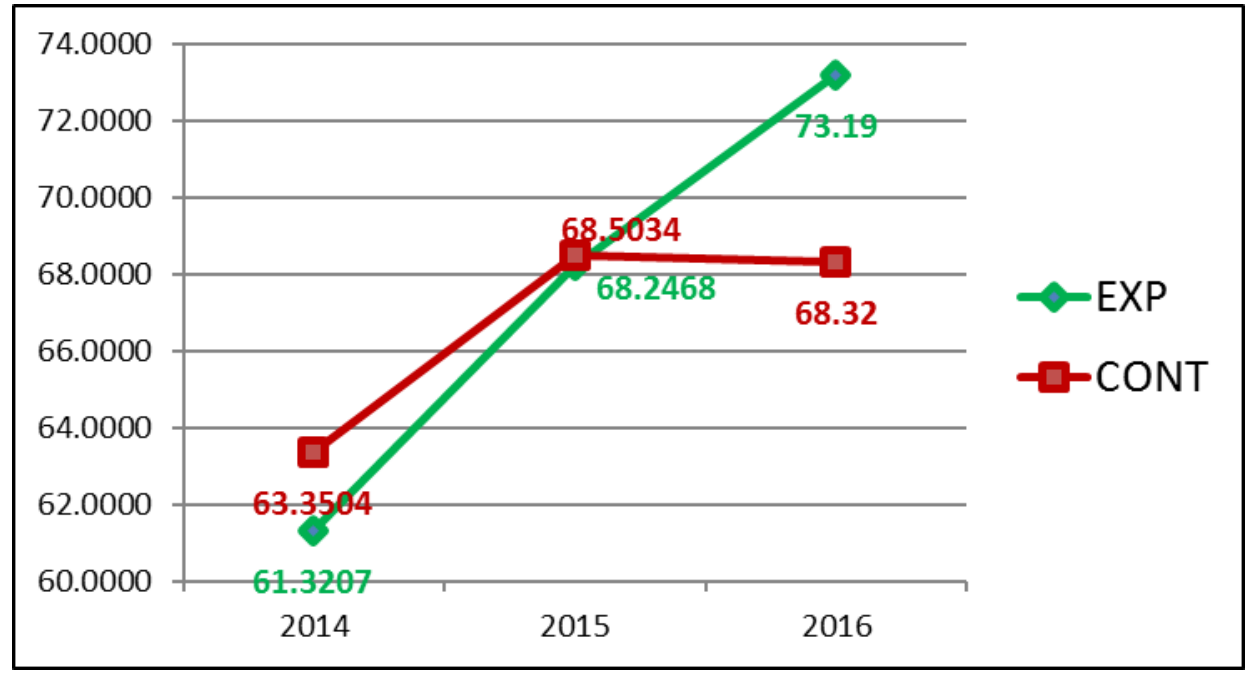

Figure 4. Comparison of Students' Performance in Science Across Three Years

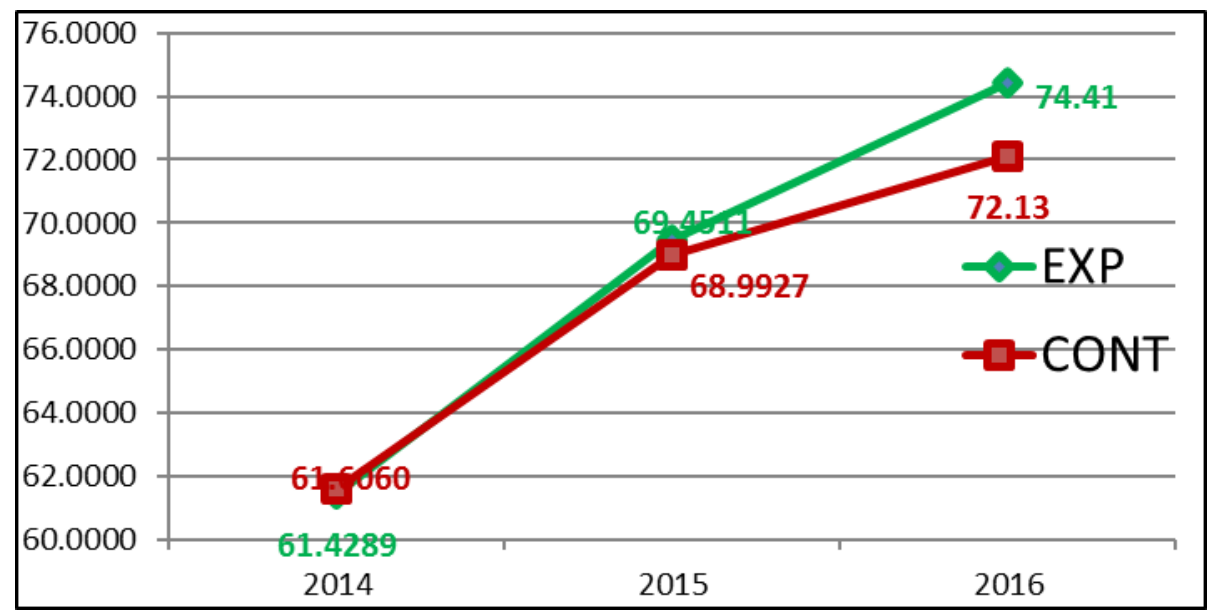

Figure 5. Comparison of Students' Performance in English Across Three Years

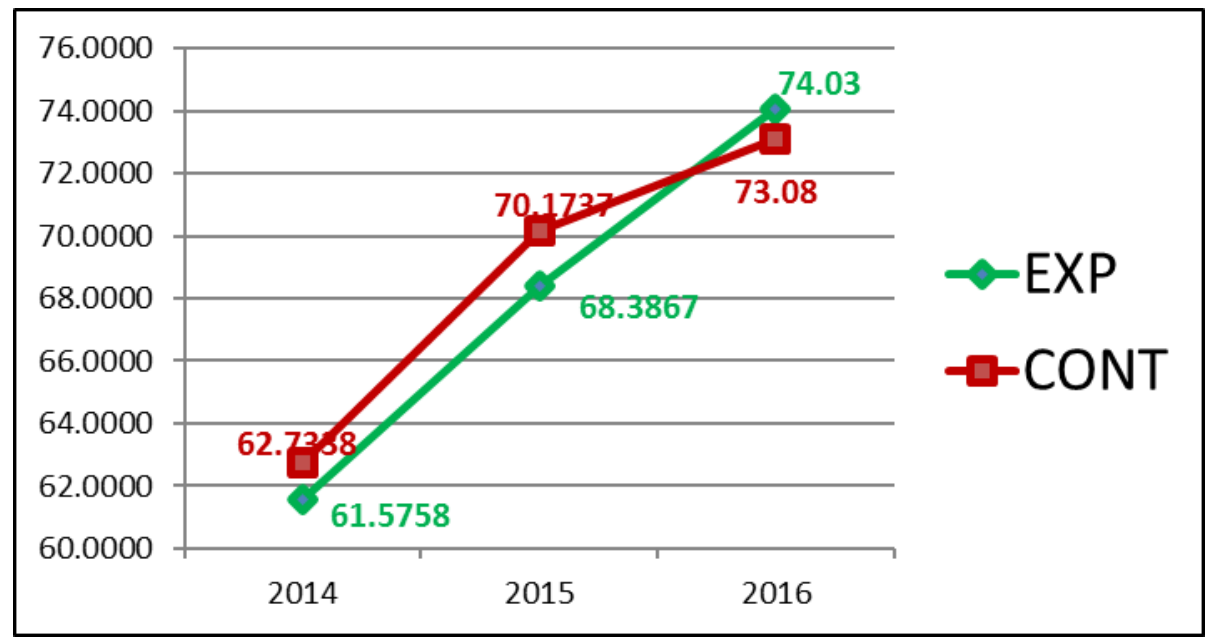

Figure 6. Comparison of Students' Performance in Arabic Language Across Three Years 


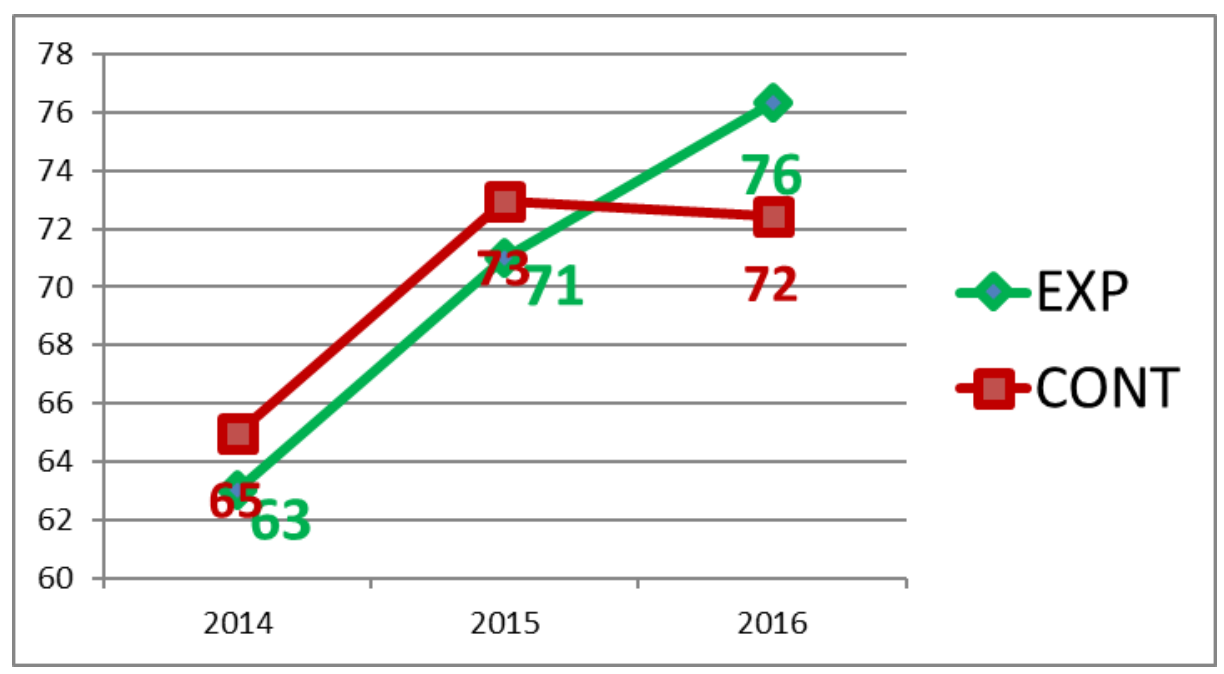

Figure 7. Comparison of Students' Performance in IT Across Three Years

With reference to question two regarding examining the difference in students' performance between the control group and the experimental group students in each of the 5 subject matter areas, table 2 and figures (2-6) above illustrate that the experimental group students significantly outperformed their counterparts in the control group in all five subject matter areas at 0.01 level of significance.

To address the third question with regard to comparing the students' performance in the experimental across time, a One Way Analysis of Variance (ANOVA) and Post Hoc tests were performed as shown in the following three tables.

Table 3. Means and Standard Deviations of the Experimental Group Performance by Year

\begin{tabular}{llll}
\hline Years & N & Means & SD \\
\hline 2016 & 2906 & 73.67 & 14.60 \\
2015 & 2590 & 68.50 & 24.50 \\
2014 & 2237 & 61.60 & 31.34 \\
Total & 7733 & 68.43 & 24.24 \\
\hline
\end{tabular}

Table 4. One Way Analysis of Variance to Compare the Students Performance Across Three Years

\begin{tabular}{lcllll}
\hline & Sum of Squares & df & Mean Square & F & Sig. \\
\hline Between Groups & 183994.801 & 2 & 91997.401 & 163.100 & .000 \\
Within Groups & 4360149.937 & 7730 & 564.056 & & \\
Total & 4544144.738 & 7732 & & & \\
\hline
\end{tabular}


Table 5. Post Hoc Tests Comparison

\begin{tabular}{cllll}
\hline \multicolumn{2}{l}{ (I) Time } & Mean Difference (I-J) & Std. Error & Sig. \\
\hline $\mathbf{2 0 1 6}$ & 2015 & $5.20423^{*}$ & .64178 & .000 \\
& 2014 & $12.06497^{*}$ & .66802 & .000 \\
$\mathbf{2 0 1 5}$ & 2016 & $-5.20423^{*}$ & .64178 & .000 \\
& 2014 & $6.86074^{*}$ & .68551 & .000 \\
\multirow{2}{2014}{} & 2016 & $-12.06497^{*}$ & .66802 & .000 \\
& 2015 & $-6.86074^{*}$ & .68551 & .000 \\
\hline
\end{tabular}

As shown in tables 3, 4, the findings reveal significant differences in the means of students' performance in the three years. Moreover, to pinpoint uncover the nature of significance, a Post hoc test in Table 5 clearly indicates gradual progressive significant improvement in students' achievement across the three years. That is to say, due to the treatment, significant progression at the 0.01 level was found from 2014 to 2015, and from 2015 to 2016.

\section{Discussion of Findings and Conclusions}

The findings of the study reveal that the experimental and the control groups' overall performance in the five subjects collectively progressed over the three years. However, in the last year the experimental group students outperformed their counterparts in the control group at the 0.01 level of significance. This overall difference in students' performance was also reflected in each of the five subjects at the same level of significance (0.01). Moreover, due to the treatment, significant gradual progression in the experimental group students' achievement across the three years was observed.

The place of this study's findings showed relevance to the existing literature in the area of school improvement. In response to the increasing demand for major reforms and transformation of educational systems, a number of school improvement models have been developed and tested in various education systems around the world (see, for example, Creemers and Kyriakides, 2010b; Creemers and Kyriakides 2012; Cruddas, L. 2007; David and Carol,2012; Eric et al.,2012; Evans, M. J., \& Cowell, N. 2013; Kyriakides, L. 2011; Kyriakides \& Creemers, 2008; Leithwood, K., \& Jantzi, D. 2006; Morgan, 1998; Mosteller and Boruch 2002; O'Hanlon \& Weiner-Davis, 1989; Schein, 2004; Slavin 2002; Stobie, Boyle, \& Woolfson, 2005). Most of the school improvement models demonstrated that systemic approaches to educational reform produce positive changes in the school operational processes and result in significant increases in student achievement (City, Elmore, Fiarman, \& Teitel, 2009; Darling-Hammond et al., 2002; Dufour et al., 2005; Leithwood et al. 2007; Stevens\& Kahne, 2006). According to Brunings (2014), opening channels of communication and networks among concerned stakeholders results in optimal learning empowerment and produce exceptional learners. 
The findings of this study is also supported by Thoonen et al. (2012), who conclude that change is considered an important part of a larger process in which teachers work and live through individual and collective reflection on beliefs and practices. Their empirical-rational approach focusses on research-based models for change which assume that teachers, as rational human beings, will implement changes in their classrooms which are demonstrated to improve student learning. In addition, Hopkins and Renolds (2001) and Leithwood, \& Jantzi (2006) state that the inside view is represented by a wide range of studies about organizational learning, learning organization, and professional communities by focusing on the capacity of schools to transform themselves into supportive environments for teacher learning and change. In these studies, organizational conditions including leadership are the main agents of school's capacity to change and a prerequisite for linking teachers' professional development to school development

Based on these findings it can be concluded that overall school improvement leads to improved students learning performance. This was reflected not only in the overall student performance of the five major school subjects, but also was reflected in improved students performance each single subject area. The more activation of the number of the driving forces in the sustainability wheel impacts the gradual level of students performance overtime, thus activating all the driving forces is deemed to sustainable improvement in students learning overtime. It is important, therefore, that each school embed the concept of quality improvement into its own subsystems of leadership, professional development, teaching, and learning environments.

\section{References}

Al- Barwani, T. A., \& Osman, M. E. (2011). Promoting Students Learning through Sustainable Innovations: Where is the missing link? In MacBeath, J. and Townsend, T. (Eds. Pp. 845-865), International Handbook on Leadership for Learning: Springer Publishers.

Berends, M., Bodilly, S., \& Kirby, S. (2002). Facing the Challenges of Whole-School Reform: New American Schools After a Decade. Santa Monica, CA: RAND.

Brunings,J. (2014). What big business can learn from a small school. Retrieved from https://onstrategyhq.com/resources/what-big-business-can-learn-from-a-small-school/

Creemers, B.P.M., \& Reezigt, G.J. (1997). School effectiveness and school improvement: Sustaining links. School Effectiveness and School Improvement, 8(4), 396-429.

Creemers, B.P.M., \& Reezigt, G.J. (2005). Linking school effectiveness and school improvement: the background and outline of the project. School Effectiveness and School Improvement, 16(4), 359-371.

Crowley, J.J., \& Hauser, A.G. (2007). Evaluating Whole School Improvement Models: Creating Meaningful and Reasonable Standards of Review. Journal of Education for $\begin{array}{lllll}\text { Students } & \text { Placed } & \text { at }\end{array}$ 
https://doi.org/10.1080/10824660701247242

Edutopia Magazine. (2005). Ten ways of School Improvement. Retrieved from http://www.edutopia.org/big-ideas-better-schools

Evans, M.J., \& Cowell, N. (2013). Real school improvement: is it in the eye of the beholder?, Educational Psychology in Practice: theory, research and practice in educational psychology,29(3), https://doi.org/10.1080/02667363.2013.798720

Franklin, C., Moore, K., \& Hopson, L. (2008). Effectiveness of Solution-Focused Brief Therapy in a School setting. Children Schools, 30(1), 15-26. https://doi.org/10.1093/cs/30.1.15

Hargreaves, A. (1995). Development and Desire: A Postmodern Perspective. In Guskey, T. and Huberman, M. (Eds.), Professional Development in Education: New Paradigms and Practices. New York: Teachers' College Press

Hopkins, D (1994). Towards a Theory for School Improvement, Paper presented to the ESRC Seminar series on School Effectiveness and School Improvement, Newcastle University. October 1994.

Hopkins, D., \& Harris, M. (1997). Understanding the School's Capacity for Development: Growth Stages and Strategies. School Leadership and Management, 17(3), 401-11.

Hopkins, D., \& Reynolds, D (2001) The Past, Present, and Future of School Improvement: Towards the Third Age. British Educational Research Journal, 27(4), 459-75

Leithwood, K.A., \& Aitken, R. (1995). Making Schools Smarter: A System for Monitoring School and District Progress. Thousand Oaks, Calif.: Corwin Press, 1995.

Leithwood, K.A., \& Jantzi, D. (2006). Transformational Leadership for large-scale reform: Effects on students, teachers, and their classroom practices. School Effectiveness and School Improvement, 17, 201-227.

Mortimore, P. (1991). School effectiveness research: which way at the cross-roads? Paper presented at the Fourth International Conference for School Effectiveness and Improvement, Cardiff.

Mortimore, P. (1993). School effectiveness and the management of effective learning and teaching. School Effectiveness and School Improvement, 4(4), 290-310.

Reezigt, G. J. (Ed.) (2000). Effective School Improvement: First Theoretical Workshop/ Contributions from Relevant Theoretical Traditions. Groningen: GION, Institute for Educational Research, University of Groningen.

Reezigt, G.J., \& Creemers, B.P.M. (2005). A comprehensive framework for effective school improvement. School Effectiveness and School Improvement, 16(4), 407-424.

Scheerens, J. (1992). Effective Schooling: Research, Theory and Practice. London: Cassell.

Sleegers, P., \& Leithwood, K. (2010). School development for teacher learning and change. 
In P. Peterson, E. Baker, \& B.McGaw, (Eds.), International encyclopedia of education (Vol. 7, pp. 557-562). Oxford, UK: Elsevier.

Thoonen, E.E.J., Sleegers, P.J.C., Oort, F.J., \& Peetsma, T.T.D. (2012). Building schoolwide capacity for improvement: the role of leadership, school organizational conditions, and teacher factors. School Effectiveness and School Improvement, 23(4), 441-460. https://doi.org/10.1080/09243453.2012.678867

\section{Copyright Disclaimer}

Copyright for this article is retained by the author(s), with first publication rights granted to the journal.

This is an open-access article distributed under the terms and conditions of the Creative Commons Attribution license (http://creativecommons.org/licenses/by/3.0/). 